\title{
Townscape as text: the topography of social interaction in Fethard, county Tipperary, AD 1300-1700
}

\author{
Tadhg O'Keeffe \\ Department of Archaeology, National University of Ireland, Dublin (UCD)
}

\begin{abstract}
Social order within medieval towns was simultaneously created by and reflected in the macro-scale structuring of the townscape and the micro-scale structuring of the buildings within it. Observed changes in the layout and architecture of towns through the medieval and early modern periods reflect changes in the practices of social interaction. This matter is explored in this paper in the context of Fethard, county Tipperary, where medieval fabric is exceptionally well-preserved.
\end{abstract}

Key index words: medieval, urban, architecture, habitus, enclosure.

\section{Conceptualising townscapes}

Occupants of medieval rural habitats may have regarded towns as places of social homogeneity. First, urban environments were defined in the landscape by town walls, mental barriers as well as physical barriers, and entry through those walls was regulated for and by those who resided within. Secondly, town walls gave spatial definition to the particular tenurial arrangement of which burgesses were the product, and possession of property by burgage tenure was sufficiently envied among rural folk that the promise of burgess status could entice migration from the countryside of one region to the urban habitat of another, as happened in Ireland (Otway-Ruthven, 1968: 116). But urban society was not static for the duration of the middle ages. On the contrary, the urban market-place provided opportunities for upward social mobility, just as the urban constitutions which ensured the steady heartbeat of urban life in the middle ages also empowered certain individuals within that society. Medieval townscapes communicated this diversity in contemporary urban social order by providing perpetual canvases for both the display of wealth and the expression of political influence, and, conversely, by rendering lower levels of wealth less easily concealed. That information is still available provided the evidence of the townscapes can be read.

The idea that complex social order in the past can be 'read' in the built environment, and indeed in material culture - tangible artefacts and landscape phenomena - in general, is a foundation of contemporary archaeology and historical geography. In the context of research on the middle ages, it is an idea which allows the development of a discourse which makes use of, but is not reliant on, historical documentation. This perspective, with its clear linguistic analogy, is broadly structuralist: it draws from structural anthropology the notion that culture is constituted as a system of signs, and that anthropology is itself drawn from a theory of linguistics which holds that language (langue), not speech (parole), is the medium of communication (for summaries and references to key texts see Burke, 1992: 110 and Buchli, 1995). Deployed in the context of an urban environment, such a linguistic analogy entices the researcher to view the elements of townscape - streets and buildings, open spaces and closed spaces - as individually having meaning and as collectively sharing grammatical relationships with each other. Whilst an evaluation of structuralism and its place in contemporary historical science lies beyond the scope of this paper, several of its constituent ideas form a conceptual underpinning for the type of analysis of a townscape which is offered below. There is a need to begin, therefore, by discussing those ideas.

Elements in townscapes do indeed have meaning, at least in the sense that people who move around towns know how to behave within those towns because they can interpret the physical environment. They 
know, for example, that a large, open-air paved area towards which streets lead is an area of open access, but that they should not venture through open gates and down narrow passages between buildings; they know also that a spire or steeple indicates a church, and that large windows at ground floor level suggest commercial buildings. The analogy is clear: urban space is negotiated by understanding what its components 'mean', just as people communicate verbally by understanding what words mean. But meaning in material culture is not fixed. On the contrary, meanings are multiple and historically-particular. A fortified stone house could have been understood among different people in the fifteenth century as communicating power, prestige, privilege, corruption, or oppression, and by the twentieth century those meanings will have been replaced by new meanings, only some of which will draw on the concept of heritage. To develop this point according to an poststructuralist perspective (Shanks and Tilley, 1987), this multiplicity of interpretations can be manipulated by powerful individuals at any moment in time so that one interpretation achieves dominance, and it is by this exercise of control over how a culture or society understands its physical environment that social structures and social hierarchies are sustained and reinforced. The linguistic analogy is again appropriate: literacy is empowering.

The second point - that elements of material culture conform to a grammar - is, at its most simple level, both an amplification of the idea that each of those elements has meaning and a recognition that meaning can be conditioned by context. For example, what words mean is understood according to their context in sentences, strings of words which conform to rules. Art historians were thinking in this way about motifs and compositions a century and a half ago (Owen, 1856; Blanc, 1867). More recently, Henry Glassie has used this idea to develop an interpretative model of vernacular houses in eighteenth-century Middle Virginia (1975). According to his model, the builders of those houses chose basic geometrical units as the starting points for construction, and then created a grammar of spatial forms in the three-dimensional architectural forms. That grammar functioned metaphorically: technological competence was put at the service of social ideology, as changing social relations between and within both households and communities found conscious embodiment in the complexity or simplicity of the designs of buildings. Matthew Johnson has also related the layout, decoration and technology of houses, and particularly the change from houses of open-hall plan to those which are internally sub-divided, to complex social changes between the fifteenth and seventeenth centuries (1993).

The value of these essentially structuralist approaches is that they articulate explicitly, and thus require thought about, two related points. First, while material culture may remain physically unchanged through time, the meaning of that material culture is ever-changing. Secondly, material culture does not passively reflect events and processes recorded in contemporary documentation but is an active agent of social change or of social stasis. For example, it can be understood how a medieval town wall would no longer have the same meaning in an early post-medieval context as it had at the time of its construction but that it could continue to shape the activities and identities of the people within it, and that by the conscious destruction of its fortified gates an urban community had a means of freeing itself, at least metaphorically, from its medieval past.

Given the survival there of considerable public and private architecture from the late medieval and early modern periods (Figure 1), Fethard, a small market town north of Clonmel in south Tipperary, is an appropriate subject for an exploration of the idea that long-forgotten social practices and interactions can still be 'read' in what remains today of the built environments which gave meaning to those activities.

Outlines of Fethard's topographical development in the middle ages have already been published by this writer, and a more comprehensive study, which includes the evidence of the eighteenth and nineteenth centuries, is in preparation (O'Keeffe, 1996a; 1998: 90-93 and forthcoming). Although Fethard's history begins at least as early as the start of the thirteenth century, the year 1300 has been chosen as a starting point for this study because the town was apparently walled for the first time a mere eight years earlier (see Thomas, 1992: 102-3 for primary references to Fethard's murage grants), and the implications of the town 


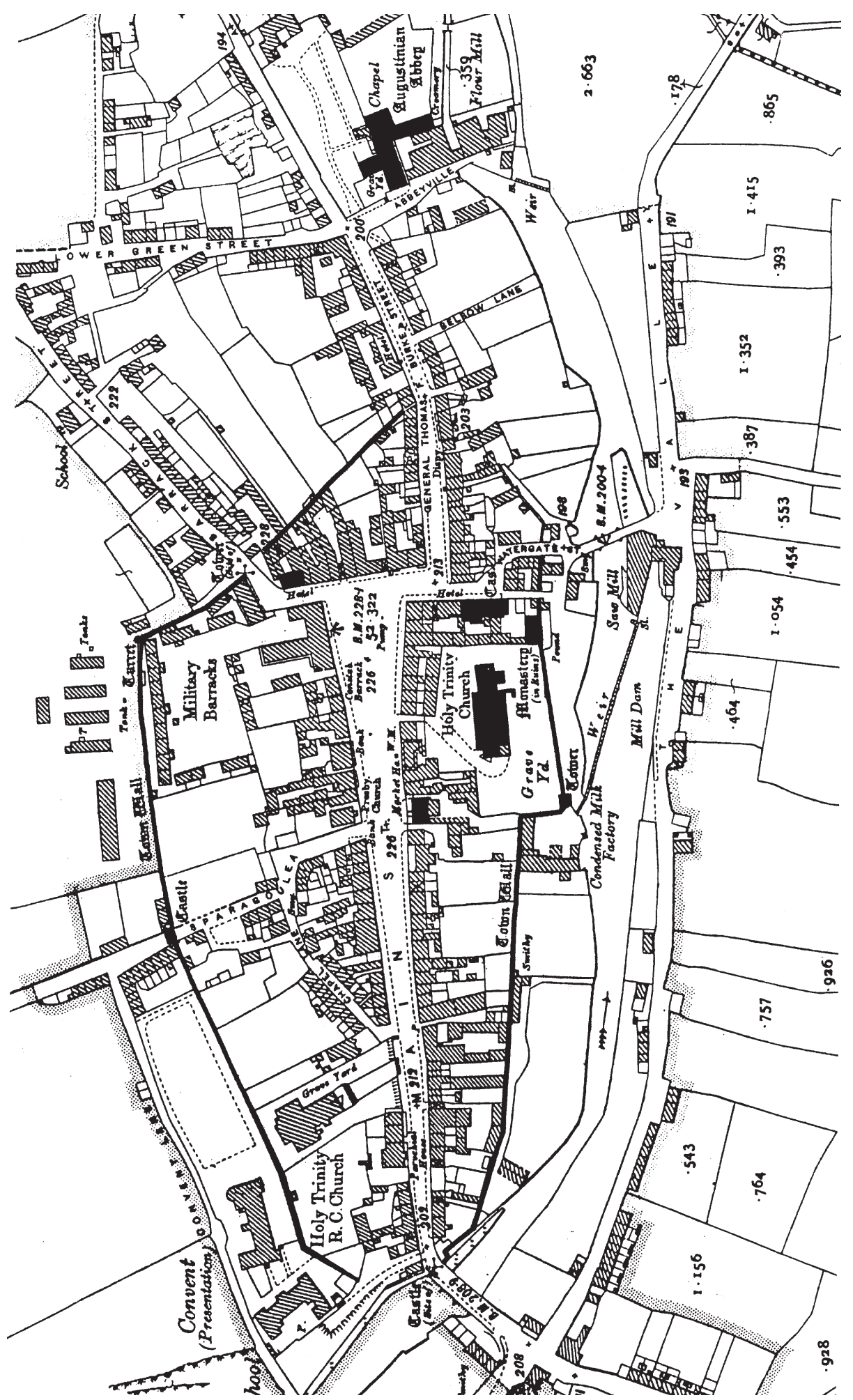

Figure 1: Medieval and early modern (pre-1700) structures in Fethard. These are marked in black on the 1905 Ordnance Survey 1:2500 town plan. The building marked 'Hotel' at the north-eastern side of the walled town was a house of c.1600 and it was demolished in 1993. 
wall for the spatial development of settlement and the social development of the town community are matters of interest here. This survey ends about 1700: records of meetings of the town corporation, founded by charter in 1552 and then renewed and enlarged by a second charter in 1608 (NLI Ms 5857), only survive from 1707 (NLI Mss 5858, 5859), while the series of fine estate maps for the town begins in 1703 (NLI Ms 21 F 55).

\section{The development of Fethard's town plan}

The actual starting date of settlement at Fethard is uncertain: settlement on the low hill-top on which the town is sited may have been created de nuovo in tandem with the formal constitution of Fethard as a borough under William de Braose's patronage between 1201 and 1208. However, Fethard's association with the archbishops of Cashel from 1215 to the middle of the sixteenth century, and similarities between the plans of its market-place and that at Cashel (O'Keeffe, 1995: 160-1), may suggest that nucleated settlement at Fethard only began in earnest under ecclesiastical patronage.

Whatever the date of its creation, the Anglo-Norman town was given quite a regular plan, with a main thoroughfare, also the market-place, running from west to east, and a parish church which was placed on the edge of the river terrace to its south. The exact boundary of the Anglo-Norman town can only be reconstructed conjecturally (Figure 2). The curving Chapel Lane, identified in this reconstruction as representing the exterior of the town's original thirteenth-century boundary, may reflect, as Dargan has noted (1997: 12), the circuit of a pre-Norman ecclesiastical vallum (Figure 3); the implication of continuing its line along the natural river terrace which runs across the south side of the churchyard and parallel to the present medieval parish church is that the site of the original pre-Norman church, if such existed, is less likely to be in the present churchyard which is at the edge of that putative enclosure than somewhere to its north, perhaps beneath the great triangular market-place which occupies the highest ground in the town.

Topographical developments in Fethard in the fourteenth century are not well known. A house of Augustinian friars was built in 1306 to the east of the town outside the 1292 boundary (O'Keeffe, 1996a: 28-29), but there is no evidence of suburban settlement in its vicinity until the post-medieval period. There was also a murage grant in 1375-6, and in this context a stone wall was mentioned for the first time, implying that the earlier boundary of the 1290s was of earth and timber, and that the same line of enclosure was being used.

Henry IV made a further grant for the walling of Fethard in 1409; nothing is known of its details. Four decades later, in 1468, yet another grant was made, this time for the duration of twelve years, and money left over was to be used for paving the streets. Indeed, the wording of this grant implies that there had recently been a similar grant in existence, possibly for the preceding twelve years.

Most of the fabric in the present town wall can be attributed to the murage grants of the late 1400s. North Gate (Figure 4, location 2), which survives today in much reduced form, and the fortified gate on Madam's Bridge at the west end of the town (Figure 4, location 1), known from drawings by George du Noyer in the mid-nineteenth century (see O'Keeffe, 1996a: 13, 24), were probably constructed around the same time; the other town gates (Figure 4), of which little is known, were probably also built in the late fifteenth century. These murage grants allowed the town to be extended into open country on its north side (compare Figures 1 and 2), perhaps in anticipation of a population expansion; the extension of the town may equally have been motivated by a need to bring the wall as far as the two bridging points on the south and west sides of the Anglo-Norman town. One consequence, perhaps deliberate, of the enlargement of the town area was that upon entering the town through either North Gate or Watergate one had to turn to the left and then to the right before reaching the market-place; unless one entered Fethard by crossing the wellfortified Madam's Bridge, no entry route allowed direct access to the market-place.

Town gates and mural towers needed to be occupied more or less permanently, and constables were doubtless appointed for the task. Although now ruined and sealed-up, the North Gate (marked as Currikeen 


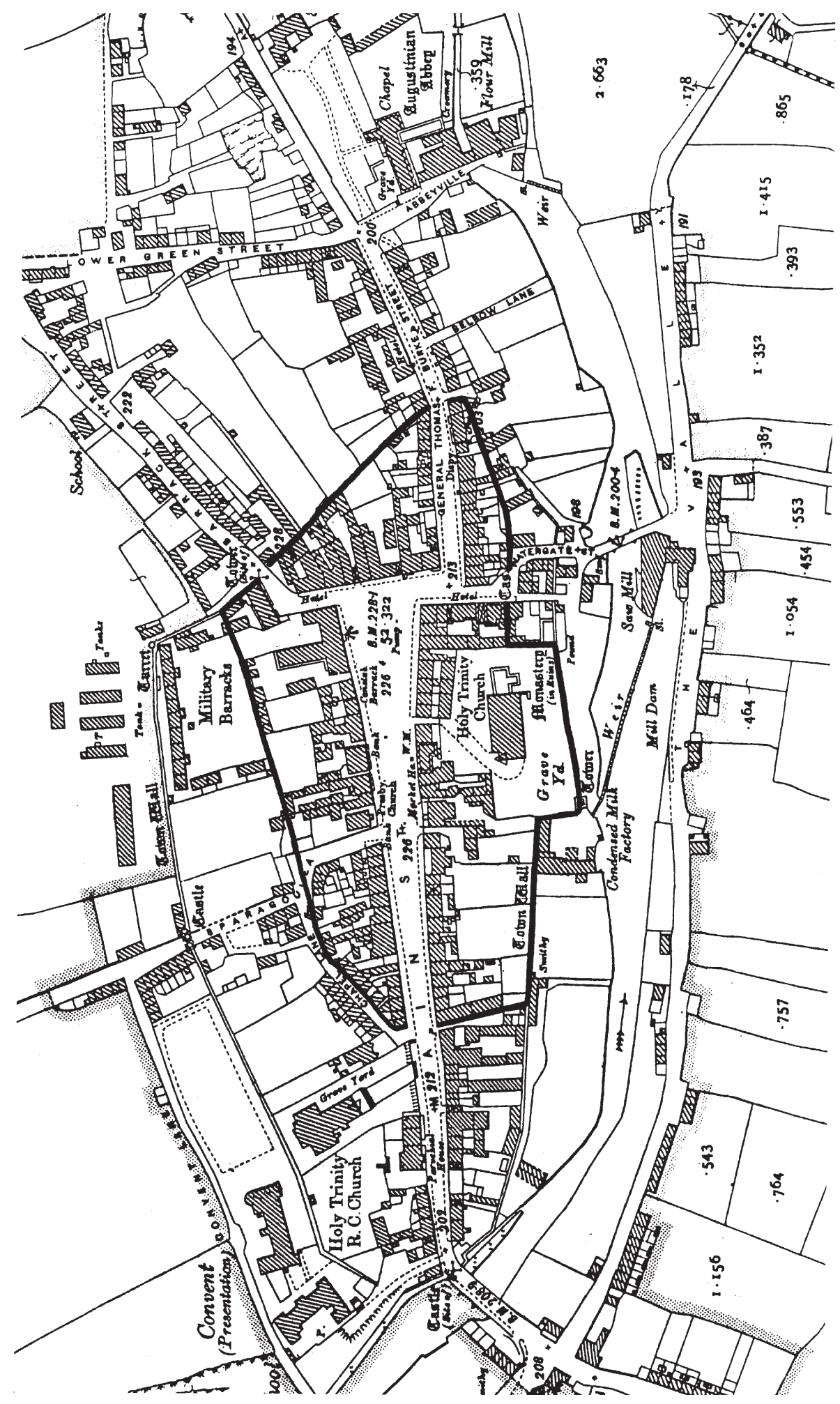

Figure 2: Conjectutal outline of the thirteenth-century town area. 


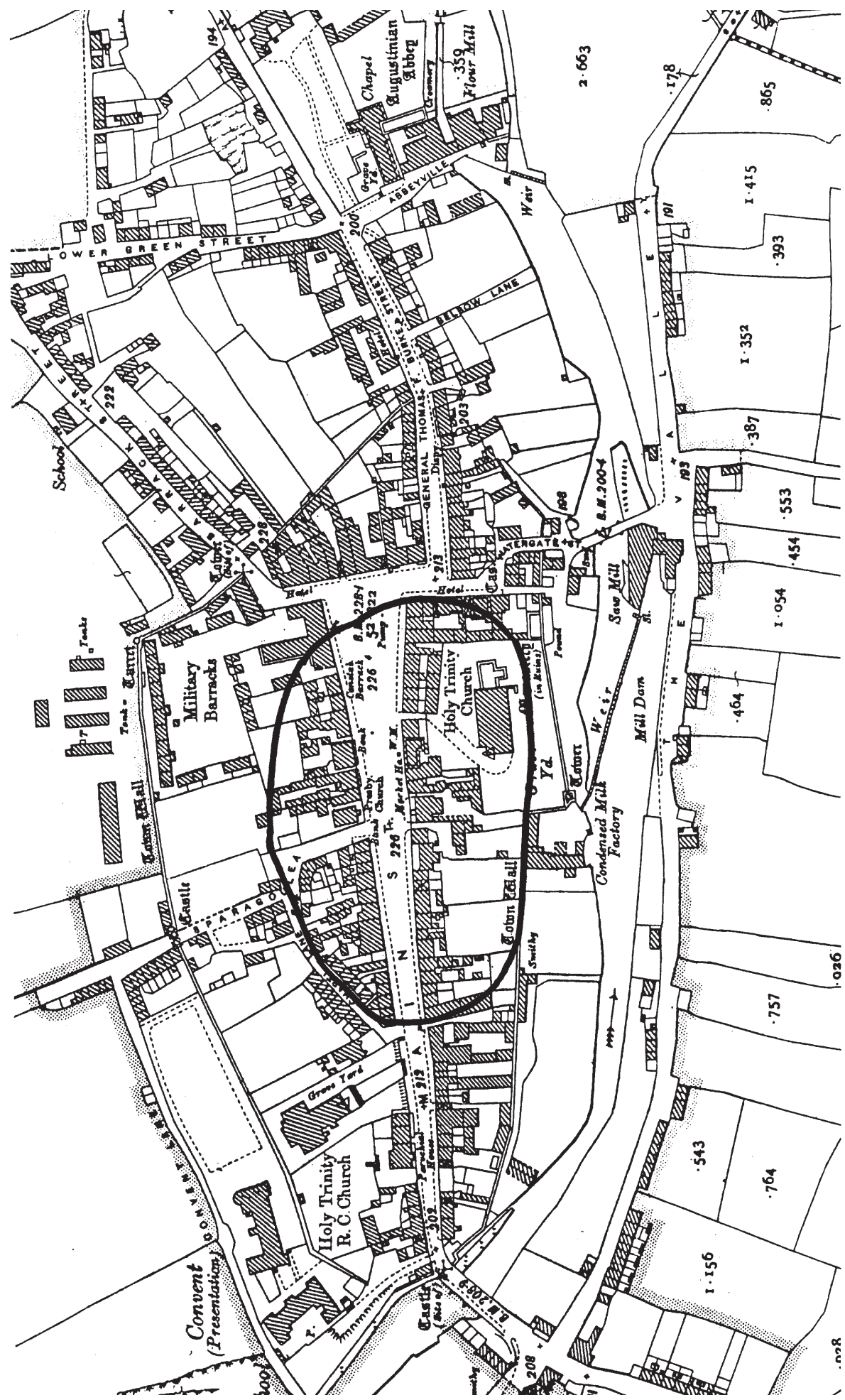

Figure 3: Conjectural outline of possible early-medieval ecclesiastical site. 
Castle on the Ordnance Survey town plan of 1840) has a residential block on its east side, although the mural tower (Fethard Castle in 1840) on the south-west corner of the churchyard (Figure 5, location 8) was somewhat less habitable. The cost of building such elaborate mural towers may explain why murage grants were needed over so long a period. Masons employed on the building of the town defences must have enjoyed employment opportunities in the private sector as well because the tower-houses inside the town, all of them built in the second half of the fifteenth century, possibly after the long murage grant of 14561480 had expired, were privately-owned and thus privately-financed. While many of the burgage plots in Fethard stretched from the street to the town wall, at least two tower-houses, those known in 1840 as Court Castle and Edmond Castle, and one early seventeenth-century stone house adjacent to Court Castle, as well as another tower-house which has been identified encased in eighteenth and nineteenth-century fabric (Figure 5, locations 5, 7, 6, 3 respectively), were built on short plots which were squeezed between the street and the churchyard. Proximity to the church was clearly of importance, and this is reflected in the architecture of these buildings, as will be shown below. It is not inconceivable that the plots which radiate around the east and north sides of the churchyard represent actual encroachment into the churchyard by wealthy burgesses wishing to have easy access to Fethard's spiritual centre.

The third phase of Fethard's pre-1700 development was in the early seventeenth century. In 1608 Sir John Everard, a scion of late medieval Fethard's most prominent family, acquired for the town its second royal charter, the first having been issued in 1552. The town's corporation was directed to build a tholsel or 'common hall' for assemblies, and this can be identified as the long, two-storeyed building located on the market-place and backing onto the churchyard (Figure 5, location 4). Sir John himself had a great house - described repeatedly in contemporary documents as a 'Mansion House' - at the north-east corner of the market-place; rebuilt in the eighteenth century and later converted into a barracks, the memory of there being a 'castle' here is recorded on the earliest Ordnance Survey map of the town in 1840 (Figure 5, location 2). Other buildings in the early seventeenth-century town were two almshouses, allegedly north and south of the church, the building of which had been planned by Sir John in honour of James I but which had not been executed until about 1612 (Everard, 1989: 542, n18); their location is a matter of conjecture. Another house of $c .1600$ was known in the nineteenth century as Stokes' Hotel (Figure 5, location 1); derelict for many years in this century, this erstwhile commercial property was eventually pulled down in August 1993.

Nothing in the surviving documentation of the early seventeenth century suggests any substantial alteration to the shape of the town, but the alignment of the façade of the seventeenth-century tholsel indicates that the buildings to its east and west occupy a street frontage of contemporary or later date. Thus it seems that the width of the market-place was altered in the 1600s. This writer has previously suggested that the market-place was widened (O'Keeffe, 1996a: 13). It now seems more likely that the tholsel was projected into the market-place from the original medieval street frontage, the line of which is represented by the tower-house which is now virtually unrecognisable beneath a later veneer (Figure 5, location 3); if this reinterpretation is correct, the properties on either side of the tholsel represent modest encroachment into the market-place.

To summarise, a shift can be detected in these phases of Fethard's development from the AngloNorman period during which Fethard's burgesses are generally anonymous in name and in deed, to the late medieval period when stratification in Fethard society manifests itself in the emergence of the perimeter of the churchyard as the prime residential area within the walls, and finally to the seventeenth century when one family - the Everards - emerged dominant in town life and effected change to the town's other great public space, the market-place. 


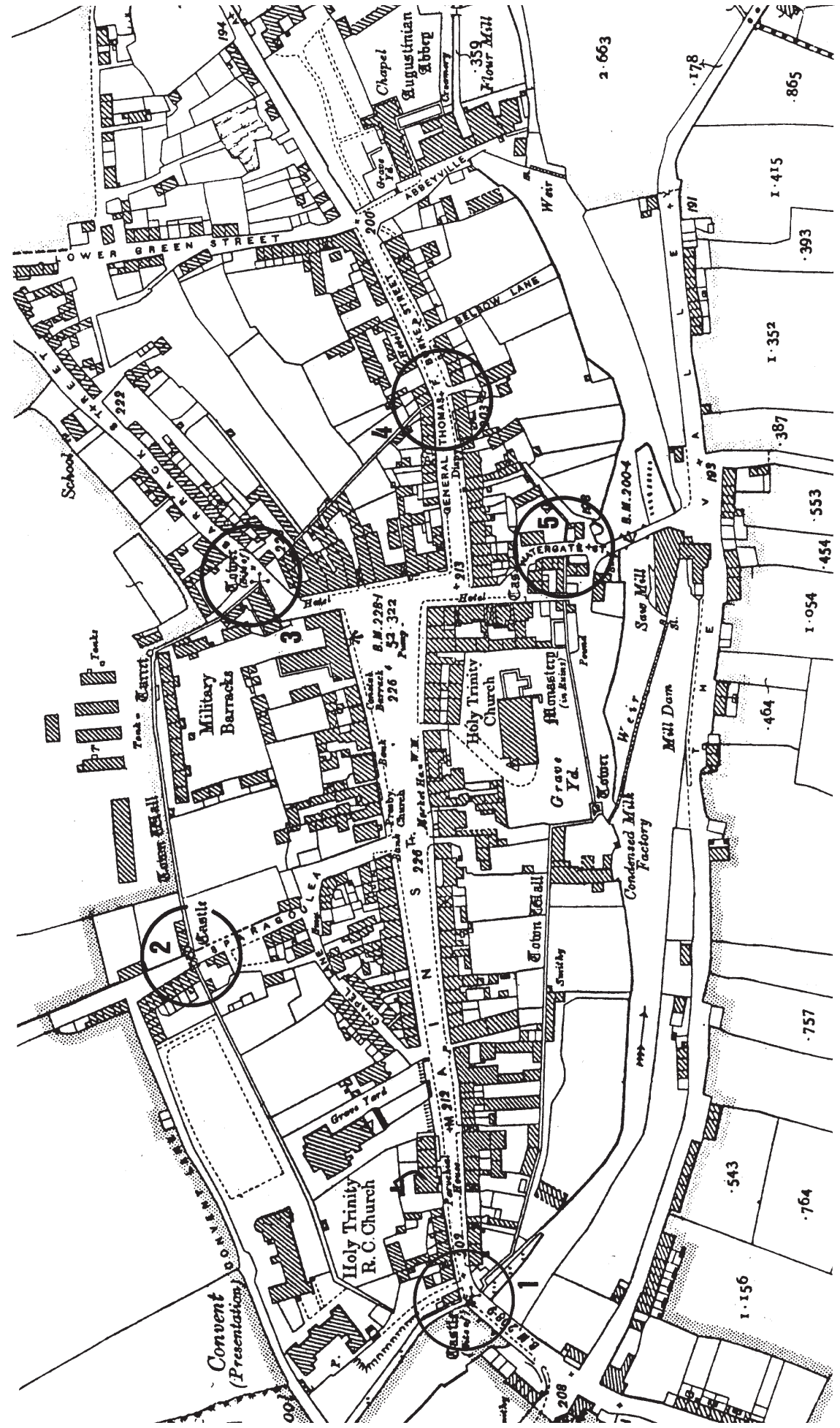

Figure 4: Town Gates: 1: West Gate/Madam's Bridge; 2: North Gate/Currikeen Castle; 3: Wickett Gate/Pierce's Gate; 4: East Gate; 5: Watergate. 


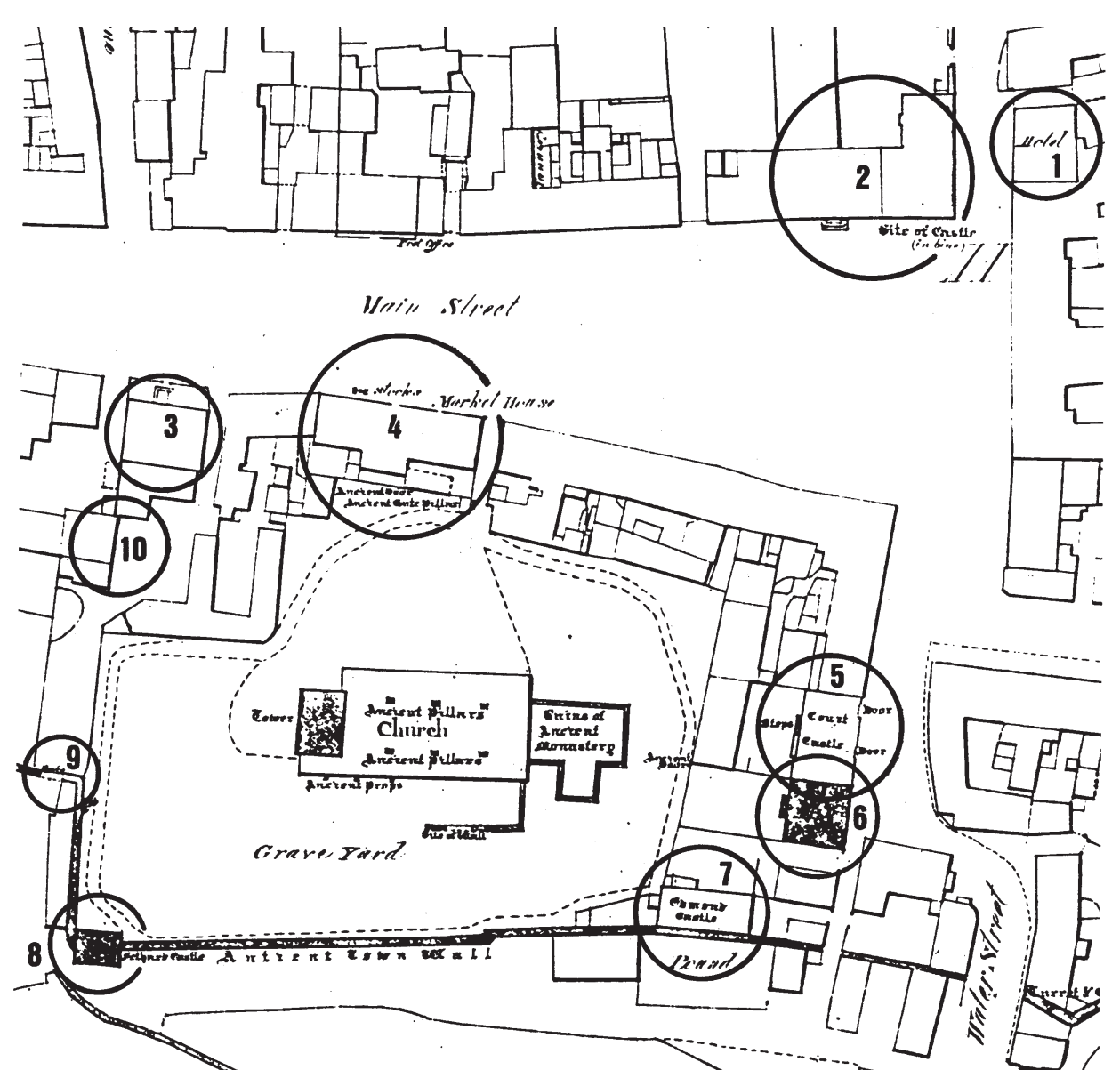

Figure 5: Detail of the area around the churchyard from the 1840 Ordnance Survey plan.

\section{Churchyard as courtyard}

The churchyard is bounded on the north and east by buildings, and on the south and south-west by the town wall. There may even have been a street running along the west side of the churchyard in the middle ages: opposite Chapel Lane (or Old Chapel lane, as it was styled in 1840) one can detect the line of a wide accessway running between the west side of one of the tower-houses (Figure 5, location 3), past the fragmentary remains of another medieval building of uncertain status (Figure 5, location 10), and terminating where a small gate (Figure 5, location 9) perforated the town wall. Thus the church appears to be centrally-located within a rectangular block of land which was defined by roads or open spaces, and which was encroached upon by buildings on only two sides.

The church itself was originally dedicated to St John the Baptist but has been dedicated to the Holy Trinity since the mid-sixteenth century. It is a nave and chancel structure with a west tower, and with a chapel and a small sacristy adjoining the south walls of the nave and chancel respectively (Figure 6). The nave and its aisles are thirteenth century in date, but the chancel is almost entirely a later medieval rebuild, and in the Victorian era the chancel arch was blocked and the high altar placed in the easternmost bay of the nave. The nave and aisles are laid out to proportions of 2:1; the width of the nave, including the aisles, is twice the width of the chancel. The western tower and the two structures projecting from the south side of the building are late medieval; they, with much of the fabric of the abandoned chancel, may date from 


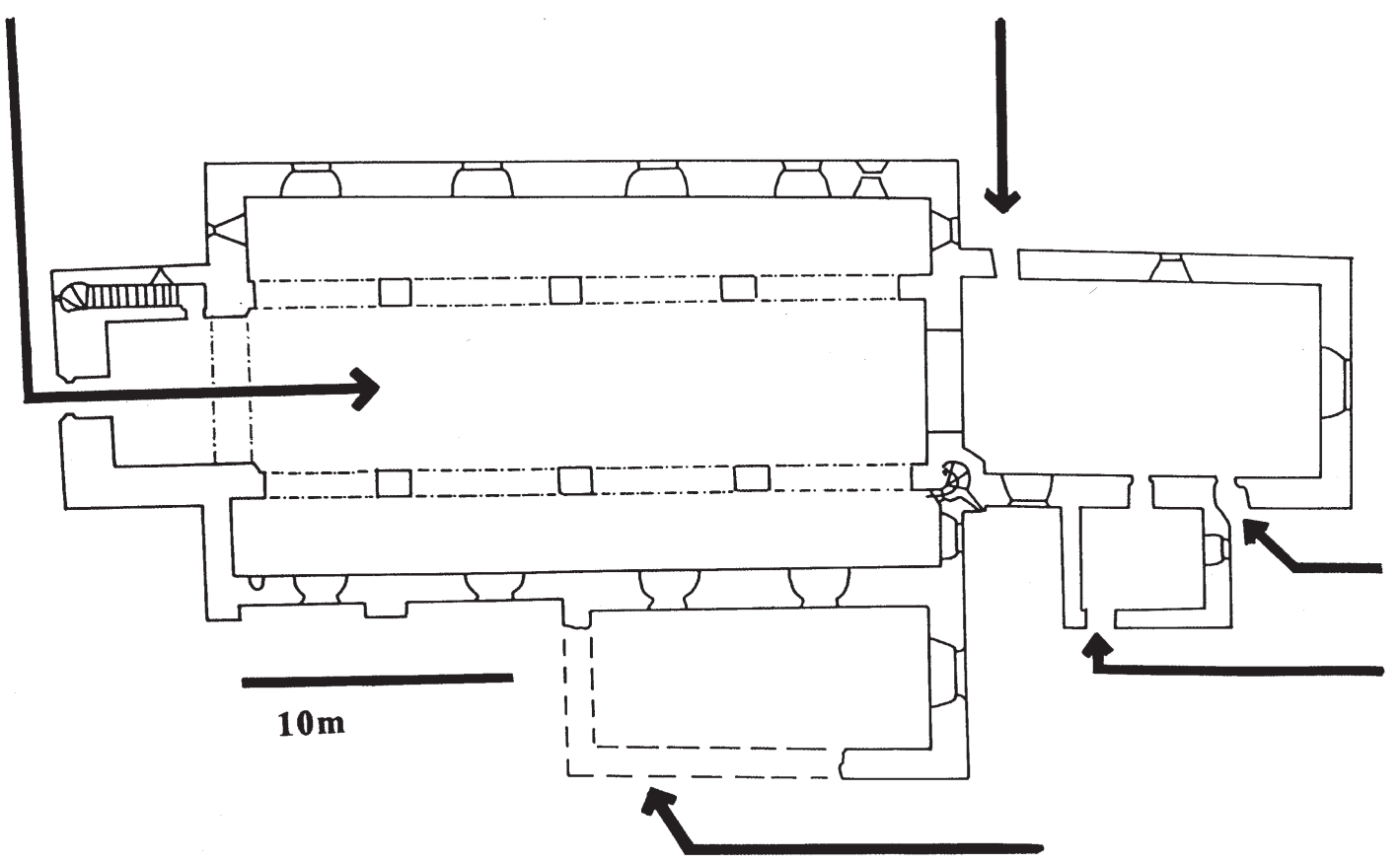

Figure 6: Simplified ground plan of Holy Trinity Church. The arrows indicate points of entry.

the early 1500s, and they might even be attributed to Edward Hackett and Annie Rokett whose repair-work at the church is recorded on their tomb of 1508 .

There were several points of entry into this church. The principal entry was from the west, through the lower stage of the large west tower; the lobby of the tower opened directly into the nave, so once inside the tower there was no barrier to the great congregational space. Entry to the chancel from the nave was probably restricted to the townspeople: parishioners, by custom, were not permitted free movement around a church's altar, and in most medieval churches (Harper, 1991: 36-38), Fethard's included, a screen or rail under the chancel arch would have communicated that prohibition. Indeed, that easternmost bay of the nave which was converted into the sanctuary in the last century may also have been out of bounds to parishioners in the middle ages: the aisle bay on the north side was effectively a small chantry chapel, and that on the south side contains the door giving access to a rood loft above the chancel arch. Three doors gave access to the chancel from the exterior, one of them through the sacristy; none is known to be earlier than the late middle ages, but that in the north wall certainly dates from the end of the middle ages or later. There was also a door into the now-ruined chapel on the south side of the nave, but it is unknown if this was in its south wall or west wall.

Proximity to the churchyard, or more specifically to the church, appears to have been important to a number of the wealthy merchant burgesses of Fethard in the fifteenth and seventeenth centuries. While it may be that fortune simply favoured those burgesses whose plots happened to be located in what was a desirable part of town, it is more likely perhaps that the known tower-houses were built by wealthy individuals who had actually purchased these plots; such an interpretation is very tempting in the case of Dalkey, county Dublin, where two urban tower-houses of the fifteenth century stand close to the medieval church, one of them occupying a site which is still visible for some distance along the medieval street. Whatever the case at Fethard, the builders of the tower-houses were certainly conscious of their proximity to the church. Both Court and Edmond Castles have dual orientations, their lower storeys opening onto the street and their upper storeys facing towards the church. There was no direct communication between the 

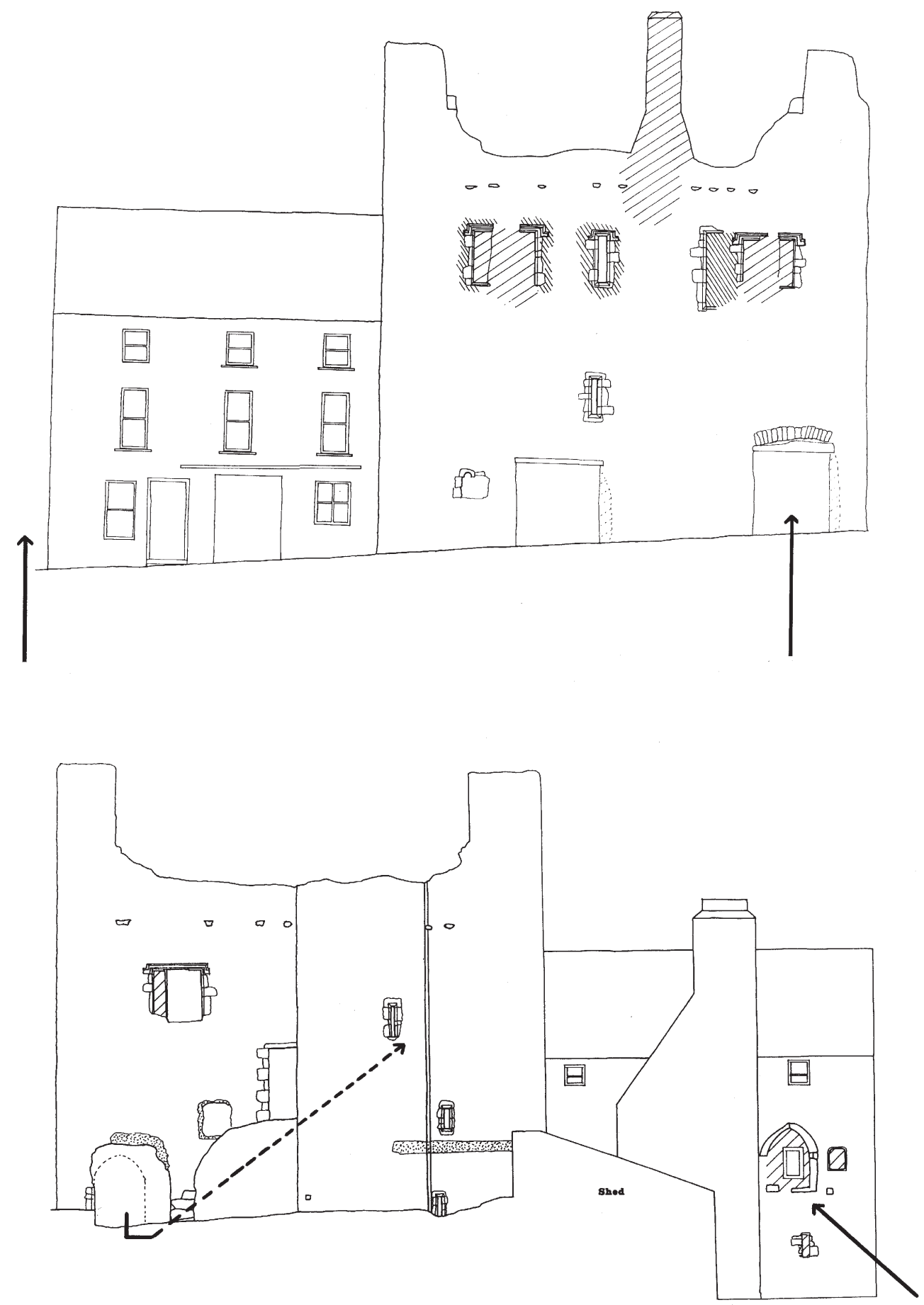

Figure 7: Street frontage of seventeenth-century house and Court Castle (top). The arrows mark the lines of entry to the rears of these properties; it is suggested that entry to the backyard of the house was not through the building but by its side. Rear elevations of the same buildings (bottom). The arrows show the lines of ascending stairs (conjectural in the case of the house) to the upper doorways. Both drawings show Court Castle prior to recent conservation and restoration. Shading represents later medieval and early-modern alterations to both buildings. 


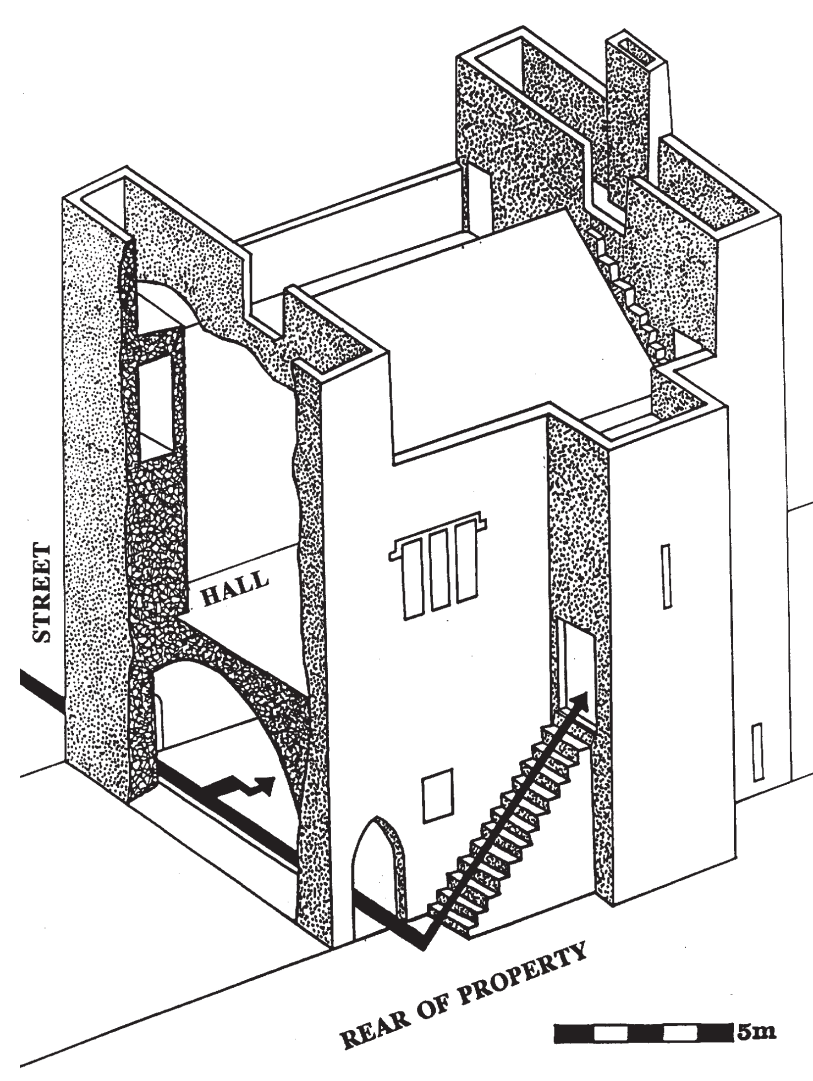

Figure 8: Schematic isometric view of Court Castle showing access from the street to the upper hall.

storeys. Indeed, for access to the upper storeys from the street one had to walk to the rears of each building along narrow corridors before ascending by external stairs which were exposed, at least in part, to the elements. This system of access survives intact at Court Castle (Figures 7, 8), but is detectable at Edmond Castle only by close scrutiny of the fabric. The seventeenth-century house adjacent to Court Castle had a comparable arrangement, although one probably had to walk around the side of the house to reach the stairs leading towards the first floor (Figure 8).

The arrangement of the interiors of these tower-houses suggests a vertical separation of functions. The upper storeys contained fine, open-roofed halls, complete with garderobes and fireplaces, indicators of comfortable living in the pre-Georgian era; Court Castle even has a laver-a stone basin contained within an arched wall-recess-for members of the household to wash their hands before eating. The lower parts of these towers were presumably commercial spaces, either retail outlets or warehouses. They were conceivably leased to commercial agents by those resident above. Their architecture further indicates that such an arrangement was not an afterthought but was envisaged when the buildings were being constructed.

It was not only the buildings which were subdivided along a vertical axis. It was also the burgage plots on which they stood. Commercial prosperity at the cores of medieval towns generally manifested itself in the longitudinal subdivision of burgage plots (Grenville, 1997: 162). However, circumstantial evidence that the original thirteenth-century plots in Fethard were too narrow to ever be divided along their long axes is provided by the access corridors which connect the fronts and backs of the tower-houses. Although contained within the tower-houses, those corridors compare so well in size and relative position with the paved, open-air passages which gave access to the backyards of the thirteenth and fourteenth-century burgage properties on North Island, Cork (Hurley, 1997), that they can be interpreted as the walled-in descendants of similar open-air passages in the burgage plots of Anglo-Norman Fethard.

The medieval occupants of Court Castle's upper hall had direct access to the churchyard through a doorway in the boundary wall of the churchyard. Access to the churchyard from Edmond Castle was even less complex: its rear wall was flush with the boundary wall of the churchyard, not separated from by it a backyard. This, combined with the fact that it was erected on the town wall of the late 1400s, its windows penetrating the publically-owned masonry, raises the possibility that it was the priest's house; its name, though, is unusual, and given that Edmond was a common Christian name among the Everards, one wonders if this tower-house represents the beginning of a process of appropriation of publicly-owned space by that family. If Edmond Castle was indeed a priest's residence, its occupant had a direct and comparatively short distance to walk to the chancel of the church. 
The ancestry of these upper-storey halls is clearly to be found in the first-floor halls of twelfth and thirteenth-century domestic architecture; this may suggest why Cairns identified Court Castle as a thirteenth-century keep (1987: 11, 33). However, the system of communication between storeys in the Fethard tower-houses is rather unusual among Irish urban tower-houses, and is certainly unusual among Irish tower-houses in general. The Fethard towers cannot, therefore, be cited as supporting evidence for Pantin's claim that medieval urban houses are essentially adaptations of rural hall-types (1962-3: 202), despite the fact that their progenitors are found frequently in rural environs.

The tholsel erected at the start of the seventeenth century also has dual orientation. One entered the lower storey through a doorway positioned centrally in its façade, but the upper storey, in which the Corporation met, was reached from the churchyard through either one of two doors positioned at either end of the building's rear wall. Both of these doorways must originally have been reached by timber stairs from the churchyard. It is not known if one could communicate between the lower and upper levels by an internal stair, and even if one existed it cannot be said with certainty that it was used on official occasions. It does seem more likely that those attending meetings -or courts - in the upper chamber entered that chamber from the churchyard. Corporation officials presumably entered through one of the two doorways, and that to the east is the likely candidate given that the parallel chancel of the church extended to the east.

The survival rate of later medieval and early post-medieval masonry in the street frontages to the north and east of the church is impressive, and it is tempting to conclude that other buildings of the same vintage are now missing. This may be true at the north end of Watergate Street, but is unlikely to be true along the south side of the market-place where the tholsel stands: both the alignment of the street frontage here and the buildings which stand along it are, apart from one tower-house (Figure 4, location 3), entirely creations of the seventeenth century and later, as has been argued, and it seems unlikely that tower-houses were cleared away to facilitate this development. It should perhaps be envisaged that the pre-1600 boundary between the market-place and the churchyard was quite a simple one, and perhaps only a wall. Indeed, the tholsel may have been the first actual building to stand squarely between the two places of congregation. Given that the only entry into the churchyard today is along a short passage bounded between the tholsel and the row of houses to its east, one wonders if access to the churchyard was restricted from the early seventeenth century.

\section{Movement and meaning}

Urban life in Fethard in the fifteenth and seventeenth centuries rotated around two adjoining spaces, the churchyard and the market-place. The most public spaces in medieval towns, these were places to which people processed and at which they congregated, although the use of each open space was scheduled, either by Christian tradition in the case of one, or by custom in the case of the other. The former presence of stone crosses on pedestals in most medieval market-places is a good indication of how the destiny of a town's commercial endeavours was viewed as a matter requiring spiritual intercession. Access from the churchyard to the corporation chamber in the tholsel could be regarded as evidence of the commercialspiritual symbiosis in the case of Fethard.

All routes from the countryside through the sites of the town gates and into the town of Fethard, with the sole exception of that along Chapel Lane, lead to the market-place. It is from there that the visitor enters the churchyard, and ultimately the church itself. Considered from the perspective of a visitor's experience of the urban space, the churchyard is the centre of the town. This sense of spatial hierarchy, with the churchyard having a higher 'rank' than the market-place because it is more deeply embedded within the townscape, must have been greater in the middle ages than it is today: the town gates were intact, and having passed through them and experienced whatever ritual was enacted by the constable for the passage of non-residents into the urban space, the visitor then had two zones of activity, or two "series of fragmented experiences" (Leech, 1997: 23), to negotiate - first the narrow corridors of urban housing, and 
then the open-air market - before reaching the churchyard. Medieval townspeople were saved the rites of passage at the town gates, but most of them had to traverse one or other, or both, zones of activity on their way to the churchyard; only those who possessed properties on the fringes of the churchyard, such as the owners of Court and Edmond Castles, were spared this circuitous pattern of movement.

A parallel but microcosmic hierarchy of space exists within the church. For most townspeople entry to the church was through the tower at its west end, and that tower acted as a barrier to the sacred space within the church just as the town gates with their towers acted as the barriers of the urban space. As noted earlier, the nave would have been separated from the chancel which lay beyond it to the east by a screen. Ritual activity within the church's sanctuary would have been concealed from view by that screen, and by the fact that the priest's back was turned to the congregation. Proximity to the chancel was a measure of social rank, and this was as true in death as in life as the tomb slabs of local gentry clustered at the east end of the church testify.

Social rank might also be encoded in the paths across the churchyard to the church. From Court Castle and Edmond Castle there was a direct route to the chancel, and the main entrance at the west end of the church could be reached by walking along the warm and bright south side of the church; for others, the route to the church was from the north, and even today one is still conscious of this being the colder and darker side of the building.

Conventional town plans do not communicate effectively the embodiment of social relationships in the configuration of urban space, but depictive models emphasising the nature of access around medieval buildings have been devised to illustrate this very matter (Faulkner, 1963; Fairclough, 1992), and this writer has used a model of this nature for an analysis of the complex tower-house of Barryscourt, county Cork (O'Keeffe, 1996). The two issues examined in this paper - the organisation of social space in the architecture of Fethard's urban environment up to the seventeenth century, and contemporary patterns of movement around and within that environment - are represented in Figure 9 in a form of access-diagram. Here it is seen that Fethard, despite its spatial irregularity on a two-dimensional map, had its social and liturgical space arranged very symmetrically.

Fethard was clearly a closed settlement system, framed both physically and metaphorically between its town wall and its parish church. The townspeople's perceptions of space between these frames only come into focus in the late 1400 s and early 1500 s when the tower-houses first appear. The dual orientation of those towers reveal that patterns of movement between the street and the churchyard were considered sufficiently important for a new form of architecture - a new grammar, to borrow Glassie's term (1975) to be created. The Corporation, conscious perhaps of the 'meaning' of dual orientation, appropriated that conception of architecture when it built its new tholsel in the early 1600s. By locating itself in the upper chamber of its tholsel and orienting itself on the church rather than on the street, the Corporation actually underscored the status of the burgesses living in the upper parts of tower-houses. Moreover, by providing their chamber with two doorways, one for its officials and one for the townspeople it served, the Corporation appears to have imitated the church and its hierarchy of entrances.

To return to the linguistic analogy with which this paper began, participants in routines of social activity reinforce and reproduce the grammar of their material environments, just as their speech perpetuates the grammatical and syntactical rules of their language (Giddens, 1982: 37). What is witnessed in the townscape of seventeenth-century Fethard could be described as the culmination of a process of grammatical evolution. Orientation on the parish church had been the formula for expressing privilege in fifteenth-century Fethard, and thus it was a formula reproduced in the early 1600s when the town's collective prosperity manifested itself in a new public building, the tholsel.

Fethard's medieval and early post-medieval townspeople may, in reality, have regarded the church and churchyard as relatively unimportant in their daily routines. But if the church and the space around it 
provided a means by which the social status of individuals and the relative prosperity of the urban collective could be measured, they must have impinged repeatedly on the consciousness of all townspeople. The very presence of the church-tower on the skyline was a reminder of the potential for self-improvement, a potential which many could not hope to fulfil. It was a reminder that urban life, for all its liberties, was ritualised. Above all else, perhaps, it was a reminder that the churchyard below had custody of the town's dead, and therefore of the town's ancestral identities.

The church and churchyard together functioned as a structure of Fethard's medieval habitus. Devised by Bourdieu as an expression of "embodied history, internalized as a second nature and so forgotten as history" (1990: 56), habitus is the system of practices by which people understand the order in their society and their place in that order. Social space, whether it is open-air or is physically-constituted as architecture, is the context in which that knowledge is acquired, and therefore the townscape, as the macro-scale visual component of the physical environment of urbanism, is charged with meaning. It was perhaps in the early seventeenth century, the period represented in Figure 9, that the meaning of the townscape of Fethard was least ambiguous.

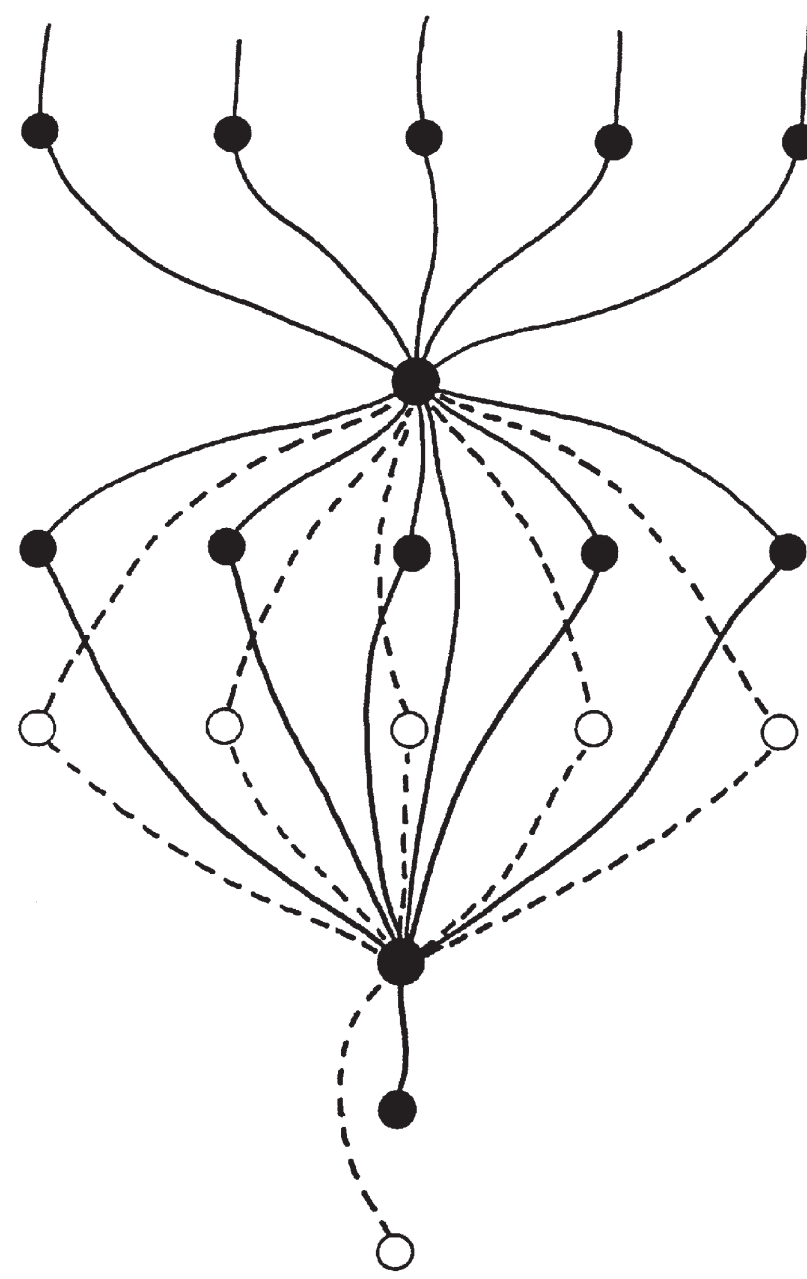

\section{Town Gates}

Market Place

Dual Orientation Buildings

\section{Churchyard}

Church Nave

Church Chancel

Figure 9: Generalised access diagram for Fethard in the seventeenth century; patterns of open and restricted movement are indicated by full and broken lines respectively; semi-public architectural spaces are indicated by full circles, and private architectural space, both domestic and liturgical, is indicated by open circles. 


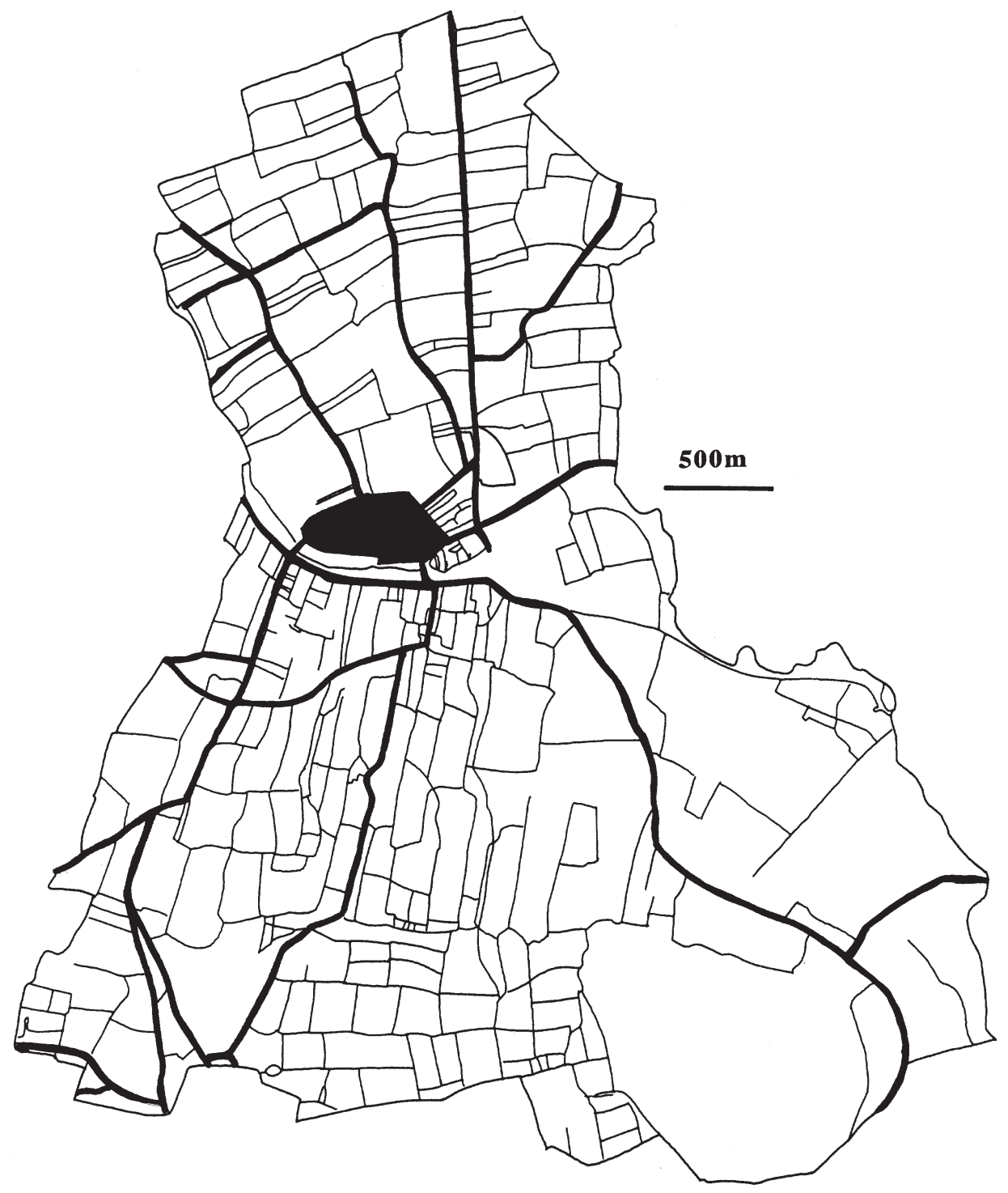

Figure 10: Fethard in its enclosed landscape setting at the end of the nineteenth century.

Epilogue: opening the town and closing the landscape

The modern traveller who approaches Fethard by road from Callan and Mullinahone will notice about a mile from the town a series of sharp right-angled bends as the road appears to side-step its way into the town. The road is clearly respecting a system of rectangular fields. The long axis of that field system is from east to west, and a comparable system of fields on the south side of the town has a north-south axis. The curvature and elongation of individual fields within these systems (Figure 10) is clearly indicative of the enclosure of medieval parcels of arable strips. These strips were presumably open in the thirteenth century in the manner of contemporary English field systems.

Oppositions between public and private, or between light and shadow, have been noted in this paper, and these observations draw implicitly on the structuralist anthropology of Lévi-Strauss (1970). Viewed from a macro-scale perspective, the most striking of the opposed relationships must have been between the 
permanent enclosure of the town in the high middle ages and the lack of permanent enclosure in the contemporary fields around it. There was perhaps an equilibrium between the enclosure of these fields and the decreasing importance of the town's enclosure in the eighteenth and nineteenth centuries. The process of field enclosure at Fethard is not known, but Johnson has identified comparable enclosed fields in England as characteristic of the piecemeal rather than rapid enclosure by consenting farmers, and his suggestion that most instances of this type of enclosure in England are 'quite early' with complete enclosure of parts of East Anglia achieved by c.1600 (1996, 53-54) has a resonance in Fethard where enclosure was already underway by 1703 when the first surviving estate map of the town was drawn.

\section{Acknowledgements}

The surveys of buildings presented in this paper were first made for a study of Fethard's architectural heritage sponsored by the National Heritage Council. I am grateful, as always, to many friends in Fethard, and particular to Joe Kenny.

\section{References}

BLANC, C. (1867) Grammaire des Arts de Dessin. Paris.

BOURDIEU, P. (1990) [1980] The Logic of Practice. Oxford: Polity Press [translated R. Nice].

BUCHLI, V.A. (1995) Interpreting material culture: the trouble with text, In: Hodder, I. (ed.) Interpreting Archaeology.

Finding Meaning in the Past. London: Routledge, 181-93.

BURKE, P. (1992) History and Social Theory. Oxford: Polity Press

CAIRNS, C. (1987) Irish Tower Houses, a Co. Tipperary Case Study. Athlone: Group for the study of Irish Historic Settlement.

DARGAN, P. (1997) The morphology of Irish towns. Part 2-The Anglo-Norman network, Geographical Viewpoint, 25, 5-17.

EVERARD, R.H.A.J. (1989) The family of Everard, Part II, The Irish Genealogist, 7, 505-42.

FAIRCLOUGH, G. (1992) Meaningful constructions: spatial and functional analysis of medieval buildings, Antiquity, 66, 348-66.

FAULKNER, P. (1963) Castle-planning in the fourteenth century, Archaeological Journal, 120, 215-35.

GIDDENS, A. (1982) Profiles and Critiques in Social Theory. London: Macmillan.

GLASSIE, H. (1975) Folk Housing in Middle Virginia: a Structural Analysis of Historic Artefacts. Knoxville: University of Tenessee Press.

GRENVILLE, J. (1997) Medieval Housing. Leicester: Leicester University Press.

HARPER, J. (1991) The Forms and Orders of Western Liturgy from the Tenth to the Eighteenth Century. Oxford: Clarendon Press.

HURLEY, M.F. (1997) Excavations at the North Gate, Cork, 1994. Cork: Cork Corporation.

JOHNSON, M. (1993) Housing Culture. Traditional Architecture in an English Landscape. London: UCL Press.

JOHNSON, M. (1996) An Archaeology of Capitalism. Oxford: Blackwell.

JONES, O. (1856) The Grammar of Ornament.

LEECH. R. (1997) The processional city. Some issues for historical archaeology, In: Tarlow, S. and West, S. (ed.) The Familiar Past? Archaeologies of Later Historical Britain. London: Routledge, 19-34.

LÉVI-STRAUSS, C. (1970) [1964] The Raw and the Cooked. London: Cape [translated J. and D. Weightman].

O’KEEFFE, T. (1995) Cashel, In: Simms, A. and Andrews, J.A. (eds) More Irish Country Towns. Cork: Mercier Press, $156-67$.

O'KEEFFE, T. (1996a) Fethard, Co. Tipperary A Guide to the Medieval Town. Fethard Historical Society.

O'KEEFFE, T. (1996b) Barryscourt Castle and the Irish Tower-house. Kinsale: Gandon Editions.

O'KEEFFE, T. (1998) Aristocrats, immigrants and entrepreneurs: settlers and settlement initiatives in late 13th century Ireland, Ruralia, II, Prague, 87-96.

O'KEEFFE, T. (forthcoming) Fethard, Co. Tipperary. Irish Historic Town Atlas. Dublin: Royal Irish Academy.

OTWAY-RUTHVEN, A.J. (1968) A History of Medieval Ireland. London: Ernest Benn.

PANTIN, W.A. (1962-3) Medieval English town-house plans, Medieval Archaeology, 6-7, 202-39.

SHANKS, M. and TILLEY, C. (1987) Social Theory and Archaeology. Oxford: Polity Press.

THOMAS, A. (1992) The Walled Towns of Ireland. Volume 2. Dublin: Irish Academic Press. 